\title{
KETUNTASAN KESIAPAN BERWIRAUSAHA SISWA SMK MELALUI PEMBELAJARAN KOLABORASI
}

\author{
V. Lilik Hariyanto \\ Fakultas Teknik, Universitas Negeri Yogyakarta \\ email: vlilik_hy@yahoo.co.id
}

\begin{abstract}
Abstrak. Tujuan penelitian ini adalah: (1) Ingin mengetahui seberapa besar tingat ketuntasan kesiapan berwirausaha siswa SMK aspek: (a) pengetahuan praktik, (b) pengetahuan kewirausahaan, (c) sikap kewirausahaan, (d) keterampilan, (e) pembuatan proposal usaha, (2) Ingin mengetahui seberapa besar tingkat keaktifan guru dalam mengajar pada aspek: (a) pendahuluan, (b) kegiatan inti, (c) penutup dan (d) penggunaan bahasa , (3) Ingin mengetahui seberapa besar tingkat keaktifan siswa dalam belajar pada aspek: (a) konsentrasi siswa saat pembelajaran, (b) mencatat, (c) bertanya kepada guru, (d) menjawab pertanyaan guru, (e) mengemukakan pendapat dan (f) penggunaan bahasa. Metode penelitian digunakan Penelitian dan Pengembangan dari Borg \& Gall. yaitu: (1) Penelitian, untuk mengumpulkan data tentang produk yang akan dikembangkan, (2) Pengembangan, untuk menganalisis produk melalui pembelajaran di kelas. Model pembelajaran digunakan Model DCRAH (Discovery, Concept Development, Resourcing, Actualizing dan Harvesting) dari Universitas Ciputra Surabaya. Penelitian dilakukan di SMKN 2 Pengasih Kulonprogo. Subjek penelitian adalah siswa kelas XII Paket Keahlian Teknik Konstruksi Batu dan Beton. Hasil penelitian menunjukkan: (1) Tingkat ketuntasan kesiapan berwirausaha siswa SMK aspek: (a) pengetahuan praktek adalah tuntas (Mean= 78,33), (b) pengetahuan kewirausahaan $($ Mean= 79,49), (c) sikap (Mean=77,57), (d) keterampilan $($ Mean $=83,62)$, (e) pembuatan proposal usaha $($ Mean=83,54), (2) Tingkat keaktifan guru dalam mengajar pada aspek: (a) pendahuluan dalam kategori aktif, (b) kegiatan inti dalam kategori aktif, (c) penutup dalam kategori sangat aktif dan (d) penggunaan bahasa dalam kategori aktif, (3) Tingkat keaktifan siswa dalam belajar pada aspek: (a) konsentrasi siswa saat pembelajaran dalam kategori aktif, (b) mencatat dalam kategori aktif, (c) bertanya kepada guru dalam kategori aktif, (d) menjawab pertanyaan guru dalam kategori aktif, (e) mengemukakan pendapat dalam kategori aktif dan (f) penggunaan bahasa dalam kategori aktif.
\end{abstract}

Kata Kunci: Pembelajaran Kewirausahaan Terintegrasi; Kesiapan Berwirausaha Siswa SMK.

Abstract. The purpose of this study is: (1) Want to know how big the vocational students completeness entrepreneurship readiness aspects: (a) knowledge of the practice, (b) knowledge of entrepreneurship, (c) an entrepreneurial attitude, (d) skills, (e) development of business proposals, (2) Want to know how much the level of activity of teachers in teaching the aspects: (a) introduction, (b) the core activities, (c) cover and (d) the use of language, (3) Want to know the extent of involvement of the student in learning the aspects of: (a) the concentration of students during the learning, (b) notes, (c) ask the teacher, (d) answer the teacher's question, (e) expression and (f) the use of language. The research method used for Research and Development of Borg \& Gall. namely: (1) Research, to collect data about the products that will be developed, (2) Development, to analyze the product through learning in the classroom. The learning model used Model DCRAH (Discovery, Concept Development, Resourcing, Actualizing and Harvesting) from Ciputra University of Surabaya. The study was conducted at SMK 2 Compassionate Kulon Progo. The subjects were students of class XII Pack Technical Expertise Stone and Concrete Construction. The results showed: (1) The level of completeness of entrepreneurship readiness aspects of vocational students: (a) knowledge of the practice is completed (Mean = 78.33), (b) entrepreneurial knowledge $($ Mean $=79.49)$, (c) attitude $($ Mean $=77.57)$, $($ d) skills $($ Mean = 83.62), (e) development of business proposals (Mean =83.54), (2) The level of activity of the teacher in teaching the aspects: (a) The introduction in the active category, (b) the core activities in the active category, (c) cover the category of very active and (d) the use of language in the active category, (3) The level of involvement of the student in learning the aspects of: (a) the concentration of students while learning in the active category, (b) recorded in the active category, (c) ask the teacher in the active category, (d) answer questions from the teacher in the active category, (e) the opinion expressed in the active category and (f) the use of language in the active category. Keywords: Integrated Learning Entrepreneurship; Readiness Entrepreneurship Students of SMK. 


\section{PENDAHULUAN}

Pendekatan ketuntasan dalam belajar merupakan pembaharuan sejak diberlakukannya kurikulum tahun 1975. Pendekatan ini difokuskan pada penguasaan siswa terhadap bahan pelajaran yang dipelajari. Siswa berkesempatan untuk maju sesuai dengan kemampuan dan kecepatan mereka sendiri. Siswa dapat meningkatkan tahap penguasaan pembelajarannya. Landasan belajar tuntas adalah pandangan bahwa semua atau hampir semua siswa diasumsikan mampu mempelajari pengetahuan, sikap dan keterampilan dengan baik asal waktu yang digunakan untuk belajar disesuaikan dengan kebutuhannya. Menurut Anderson \& Block (1987), pembelajaran tuntas adalah seperangkat gagasan dan tindakan pembelajaran yang dapat membantu siswa untuk belajar secara konsisten. Jika setiap siswa diberi waktu sesuai dengan kebutuhanya dan siswa tersebut memanfaatkan waktu yang diperlukan untuk belajar, maka siswa akan mencapai tingkat penguasaan yang optimal dalam pembelajaran tersebut.

Kesiapan (readiness), menurut kamus psikologi (Dali Gulo, 1984) adalah sesuatu titik kematangan untuk menerima dan mempraktikkan tingkah laku tertentu. Sedangkan menurut (Chaplin, 2006:49), kesiapan adalah tingkat perkembangan dari kedewasaan yang menguntungkan untuk mempraktikkan sesuatu. Dengan demikian dapat dikatakan bahwa kesiapan merupakan suatu kondisi psikologis seseorang dimana yang bersangkutan siap untuk memberikan reaksi sebagai akibat adanya aksi.

Slameto (2003:120), mengemukakan bahwa faktor-faktor yang mempengaruhi kesiapan antara lain minat, motivasi, sikap dan kepribadian. Oleh karena itu, untuk mencapai tingkat kesiapan terhadap sesuatu dipengaruhi oleh tiga faktor, yaitu: (1) tingkat kemasakan, (2) pengalaman-pengalaman yang diperlukan, dan (3) keadaan mental dan emosi yang serasi. Selanjutnya ketiga faktor tersebut menurut Sukirin dapat dijelaskan: (1) tingkat kemasakan (maturation) adalah suatu saat dalam proses perkembangan, dimana suatu fungsi fisik atau mental telah mencapai perkembangan yang sempurna dalam arti siap digunakan. Tingkat kemasakan ini banyak berhubungan dengan usia dan fisik, (2) pengalaman-pengalaman yang diperlukan adalah pengalaman-pengalaman tertentu yang diperoleh anak yang ada sangkut pautnya dengan keadaan 
lingkungan, kesempatan-kesempatan yang tersedia dan pengaruh-pengaruh dari luar yang disengaja seperti pendidikan dan pengajaran dan pengaruhpengaruh dari luar yang tidak disengaja. Karena pengalaman merupakan salah satu faktor penentu kesiapan, maka untuk menciptakan terbentuknya kesiapan terhadap sesuatu dapat direncanakan pengalaman apa saja yang harus diberikan kepada anak, (3) keadaan mental dan emosi yang serasi adalah suatu keadaan yang meliputi sikap kritis, memiliki pertimbangan-pertimbangan yang logis, obyektif, bersifat dewasa dan emosi yang terkendali. Jadi, kesiapan diartikan sebagai tingkat kesiapan yang dipengaruhi oleh faktor usia, pengalaman yang diperoleh melalui pendidikan dan lingkungan serta sikap dari siswa.

Kewirausahaan (entrepreneurship) adalah kegiatan pengorganisasian berbagai faktor produksi yang dilakukan oleh seseorang wirausaha sehingga menjadi suatu kegiatan ekonomi yang menghasilkan profit sebagai bentuk balas jasa atas kesediaannya mengambil resiko. Suryana (2006:89) menjelaskan tentang tingkatan kompetensi yang harus dimiliki oleh seorang wirausaha, yaitu: (1) Knowing your business, yaitu harus mengetahui apa yang akan dilakukan, (2) Knowing the basic bisiness management, yaitu mengetahui dasar-dasar pengelolaan bisnis, seperti bagaimana merancang, mengorganisasikan, dan mengendalikan perusahaan. Mengetahui manajemen bisnis berarti memahami kiat, cara, proses, dan pengelolaan sumber daya perusahaan secara efektif dan efisien, (3) Having the proper attitude, yaitu memiliki sikap kesungguhan terhadap usaha yang dilakukan tidak dengan setengah hati, (4) Having adequate Capital, yaitu memiliki modal yang cukup. Modal di sini tidak hanya materi tetapi juga mental spiritual menyangkut keyakinan dan keteguhan hati sebagai modal utama dalam berusaha, (5) Managing finance effectively, yaitu memiliki kemampuan mengatur keuangan secara efektif dan efisien, (6) Managing time efficiently, yaitu kemampuan untuk mengatur waktu secara efisien dan tepat guna; (7) Managing people, yaitu memiliki kemampuan untuk mengendalikan orangorang dalam menjalankan perusahaan, (8) Saticfying customer by providing high quality product, yaitu kemampuan untuk memuaskan pelanggan dengan memberikan pelayanan jasa atau barang yang bermutu, (9) Knowing how to compete, yaitu mengetahui strategi bersaing dalam dunia usaha. Seorang 
wirausaha harus dapat mengungkapkan kelemahan, kekuatan, peluang, dan ancaman pada diri dan pesaingnya, (10) Copying with regulations and paperwork, yaitu seorang wirausahawan harus memenuhi kemampuan membuat aturan kerja yang jelas secara praktis.

Pembelajaran kolaborasi pada dasarnya merupakan perpaduan implementasi pembelajaran pada lebih dari satu mata pelajaran yang saling bersinergi. Prosesnya dapat dilakukan seperti proses pengintegrasian mata pelajaran yang satu ke mata pelajaran yang lainnya. Dalam kaitannya dengan mata pelajaran kewirausahaan, Kemendiknas (2010), memaparkan bahwa proses integrasi pendidikan kewirausahaan tidak perlu membuat kurikulum baru terlebih dahulu, tetapi cukup mengintegrasikannya ke dalam komponen kurikulum. Prosedur pengintegrasian dengan mengidentifikasi jenis-jenis kegiatan di sekolah yang dipandang dapat merealisasikan pendidikan kewirausahaan terhadap kehidupan siswa setelah lulus agar dapat berwirausaha mandiri. Nilai-nilai pokok kewirausahaan yang dapat diintegrasikan menurut Kemendiknas (2010: 58-59) adalah: (1) mandiri, (2) kreatif, (3) pengambil resiko, (4) kepemimpinan, (5) orientasi pada tindakan dan (6) kerja keras.

Hasil pembelajaran yang mengarah pada tercapainya ketuntasan kesiapan berwirausaha dalam hubungannya dengan siswa SMK sebagai calon wirausaha sangat berhubungan proses penanaman pendidikan kewirausahaan. Beberapa alasan perlu dipertimbangkan dengan matang. Matthoriq, Ria Triwastuti, \& Nurul Hidayah. (2009). Menyatakkan bahwa Sekolah Menengah Kejuruan (SMK) memiliki peran yang tidak tergantikan dalam menciptakan budaya wirausaha. Alasannya: (1) SMK merupakan level pendidikan yang dapat dijangkau oleh sebagian besar masyarakat dengan berbagai tingkat ekonomi, (2) SMK merupakan institusi pendidikan menengah formal yang dikembangkan untuk mencetak lulusan siap kerja, sehingga siswa dan atau lulusannya dirasa cukup mampu untuk bekerja ditingkat menengah atau pelaksana madya yang memiliki kemampuan dan ketrampilan teknis sekaligus bisa menjadi pemikir (thinker), (3) Direktorat Pembinaan SMK telah berkomitmen mengembangkan pendidikan dan pelatihan kewirausahaan bagi siswa SMK di seluruh Indonesia. 
Atas dasar pemikiran tersebut, istilah ketuntasan kesiapan berwirausaha dalam penelitian ini dapat diartikan sama dengan kemampuan. Sedangkan sesuatu kemampuan dapat dipandang sebagai bagian paket dari elemen-elemen ketiga ranah pengetahuan, sikap dan keterampilan, (Edward, 1982). Mengingat pengetahuan, keterampilan, sikap dan nilai-nilai pada dasarnya diperoleh melalui belajar, maka ketuntasan kesiapan berwirausaha di dalam penelitian ini berhubungan dengan hasil belajar siswa baik dalam ranah pengetahuan, sikap dan keterampilan.

Penanaman kesiapan berwirausaha kepada siswa SMK merupakan aspek penting dalam menghasilkan lulusan yang mampu menciptakan lapangan kerja. Oleh karenanya diperlukan kajian implementasi model pembelajaran yang tepat. Penelitian ini bermaksud mengimplementasikan pembelajaran kolaborasi antara mata pelajaran kewirausahaan dan mata pelajaran bidang produktif dalam membentuk ketuntasan kesiapan berwirausaha siswa.

\section{METODE}

Penelitian ini menggunakan pendekatan penelitian dan pengembangan (Research \& Development), yang berorientasi pada pengembangan produk. Borg \& Gall (1989), menyatakan bahwa penelitian dan pengembangan menghasilkan produk. Produk dalam penelitian ini adalah alat ukur pembelajaran kolaborasi antara mata pelajaran kewirausahaan dan mata pelajaran produktif praktik kerja batu dan beton. Alat ukur ini berorientasi pada ketuntasan kesiapan berwirausaha siswa, yang terdiri dari aspek pengetahuan, sikap dan keterampilan.

Waktu penelitian dalam bentuk implementasi pembelajaran di kelas adalah pada bulan November tahun 2012 sampai dengan bulan Desember tahun 2012. Tempat penelitian di SMKN 2 Pengasih, Kabupaten Kulonprogo, Daerah Istimewa Yogyakarta.Target/subyek penelitian adalah Siswa kelas XII Paket Keahlian Teknik Konstruksi Batu dan Beton, SMKN 2 Pengasih, Kabupaten Kulonprogo, Daerah Istimewa Yogyakarta.

Prosedur penelitian dibagi dua tahapan: (1) pra implementasi pembelajaran meliputi: (a) persiapan instrumen-instrumen penelitian yang telah divalidasi, (b) penyamaan persepsi materi pembelajaran kolaborasi kepada masing-masing guru 
pengajar dan usur yang terkait, (c) menyiapkan sarana dan prasarana pembelajaran, (2) implementasi pembelajaran kolaborasi mencakup aspek: (a) pembelajaran kewirausahaan, (b) pembelajaran praktik konstruksi batu dan beton, (c) evaluasi.

Data penelitian meliputi: (1) hasil pembelajaran kolaborasi antara mata pelajaran kewirausahaan dan mata pelajaran produktif praktik kerja batu dan beton, yang berorientasi pada tingkat ketuntasan kesiapan berwirausaha siswa SMK aspek: (a) pengetahuan praktik, (b) pengetahuan kewirausahaan, (c) sikap, (d) keterampilan, (e) pembuatan proposal usaha, (2) tingkat keaktifan guru dalam mengajar pada aspek: (a) pendahuluan, (b) kegiatan inti, (c) penutup dan (d) penggunaan bahasa , (3) tingkat keaktifan siswa dalam belajar pada aspek: (a) konsentrasi siswa saat pembelajaran, (b) mencatat, (c) bertanya kepada guru, (d) menjawab pertanyaan guru, (e) mengemukakan pendapat dan (f) penggunaan bahasa.

Pada penelitian ini, analisis data dilakukan secara deskriptif-kualitatif dengan memberikan narasi yang logis sesuai dengan tujuan penelitian. Selain hal tersebut, data yang telah dikumpulkan dengan menggunakan instrumentinstrumen penelitian selanjutnya dianalisis secara kualitatif dan kuantitatif.

\section{HASIL DAN PEMBAHASAN}

Ketuntasan kesiapan berwirausaha siswa merupakan unjuk kerja siswa atau prestasi belajar siswa setelah mereka mengikuti pembelajaran kolaborasi antara mata pelajaran kewirausahaan dan mata pelajaran produktif praktik kerja batu dan beton. Pola pembelajaran kewirausahaan mengacu pada Model Pembelajaran Kewirausahaan di Universitas Ciputra Surabaya, terdiri dari langkah-langkah: (1) Discovery, (2) Concept Development, (3) Resourcing, (4) Actualization, and (5) Harvesting, (NCSEE, 2013).

Di awal pembelajaran kolaborasi, siswa di samping belajar materi produktif, secara bersamaan juga pada diri siswa ditumbuhkan kesiapan berwirausahanya. Salah satu cara yaitu siswa diberi tugas untuk "bermimpi" tentang kemungkinan-kemungkinan siswa agar dapat mengembangkan potensi kewirausahaannya. Siswa didorong untuk menemukan sesuatu kegiatan 
kewirausahaan yang bisa diadopsi dan disinergikan dengan pembelajaran produktif di sekolah. Siswa secara mandiri diberi tugas untuk melakukan observasi kegiatan kewirausahaan yang berkaitan dengan pengembangan Paket Keahlian Teknik Konstruksi Batu dan Beton. Untuk menunjang kegiatan tersebut, lokasi observasi difokuskan di sekitar sekolah dan tempat domisili siswa. Panduan untuk kegiatan observasi siswa merupakan angket yang telah disiapkan sebelumnya. Dari kegiatan observasi ini diharapkan muncul suatu embrio semangat untuk berwirausaha pada diri siswa, sehingga ke depan siswa mempunyai suatu bayangan tentang kesuksesan terhadap dirinya yang dicapai memalui kegiatan kewirausahaan. Proses ini merupakan tahapan Discovery.

Pada diri siswa yang telah tumbuh semangat berwirausaha, maka semangat ini terus dibangun, ditumbuhkembangkan sehingga ke depan menghasilkan suatu komitmen dalam diri siswa untuk menjadikan dirinya sebagai seorang wirausaha yang sukses. Salah satu cara menumbuhkembangkan semangat berwirausahan ini dalam kapasitas pembelajaran yaitu dengan cara siswa diberi tugas untuk membuat suatu proposal usaha. Substansi proposal usaha yang dibuat berisikan dari hasil survey materi kewirausahaan yang telah dilakukan. Siswa memilih salah satu dari sekian alternatif produk yang akan dibuat dalam pembelajaran kolaborasi. Langkah kedua dari model ini merupakan tahapan Concept Development, yang menitikberatkan pada aktivitas pemilihan pada sebuah ide dan membuat suatu perencanaan kegiatan (berwirausaha).

Perencanaan usaha yang telah ditetapkan dan tertuang dalam dokumen proposal usaha perlu diuji kelayakannya (Resourcing). Salah satu cara menganalisis kelayakan usaha adalah dengan analisis SWOT (Strength, Weaknesses, Opportunities ant Threats). Analisis SWOT mencakup lingkungan ekternal dan internal. Secara internal, kerangka kerjanya menguraikan kekuatan dan kelemahan pada demensi kunci, misalnya kinerja sumber daya, sumber daya manusia, fasilitas dan kapasitas produksi, pangsa pasar, persepsi pelanggan terhadap kualitas produk, harga dan ketersedian produk dan organisasi komunikasi. Misalnya dianalisis kelayakan produksi batako dengan kualitas baik menurut Standar Industri Indonesia. Untuk usaha tersebut, di bawah payung strength dapat diisi dengan popularitas produksi karya siswa SMK dan harga 
murah terjangkau konsumen. Di bawah label weaknesses dapat diisi dengan jenis produksi batako yang terbatas. Penilaian terhadap lingkungan eksternal termasuk informasi pasar (pelanggan dan persaingan), kondisi ekonomi, tren sosial menggunakan bahan bangunan dari batako, teknologi dan peraturan pemerintah.

Kegiatan pokok pembelajaran produktif adalah menyiapkan siswa agar terampil dalam membuat benda-benda produktif. Dalam hal ini produk hasil kerja dalam pembelajaran tidak semata-mata telah dianggap selesai, bila siswa telah menyelesaikan pekerjaannya. Namun secara sinergi produk yang dihasilkan mestinya layak untuk dimanfaatkan dalam kehidupan nyata sehari-hari, layak untuk dijual. Untuk itu, produk yang dibuat siswa harus betul-betul diperhatikan dari sisi kualitasnya. Pada tataran inilah disisipkan wawasan kewirausahaan pada diri siswa. Proses sinergi antara praktik pembelajaran produktif dan pengembangan wawasan kewirausahaan siswa yang dibangun melalui pembelajaran nyata di kelas merupakan awal dari implementasi pembelajaran senyatanya (Actualization). Pada tahapan ini siswa tidak berhenti pada tahap pembelajaran di kelas saja, namun siswa juga dituntut untuk memasarkan produk yang dibuatnya hingga laku dijual dipasaran bebas.

Produk yang telah dirancang dan dibuat harus dibuktikan layak atau tidak untuk di jual dipasaran bebas. Karya-karya produktif siswa dicoba untuk dipasarkan pada konsumen. Bagaimana respon konsumen, apakah mereka mengapresiasi dengan baik terhadap produk siswa atau bahkan konsumen mencemoohkannya. Pada tahapan inilah masa depan rintisan usaha ditentukan, yang didasari atas hasil yang didapat atau dapat dikatakan proses memanen (Harvesting/Revise).

Berdasarkan tahapan-tahapan pembelajaran seperti tersebut di atas, maka hasil pembelajaran atau unjuk kerja yang mencerminkan kesiapan berwirausaha siswa dapat diukur dari berbagai aspek. Dalam hal ini diukur berdasarkan lima aspek yaitu: (1) pengetahuan praktik konstruksi batu dan beton, (2) pengetahuan kewirausahaan, (3) sikap, (4) keterampilan praktik teknik konstruksi batu dan beton, dan (5) pembuatan proposal usaha dan pemasaran. 
Tabel 1.

Kesiapan Berwirausaha Siswa Kelas XII Di SMKN 2 Pengasih Kulonprogo

\begin{tabular}{|c|c|c|c|c|c|c|c|c|c|c|c|}
\hline \multirow{2}{*}{ No } & \multirow{2}{*}{ Nama } & \multicolumn{9}{|c|}{ Ranah Kompetensi } & \multirow{2}{*}{$\begin{array}{c}\text { Ket } \\
10\end{array}$} \\
\hline & & 1 & 2 & 3 & 4 & 5 & 6 & 7 & 8 & 9 & \\
\hline 1 & AP & 73.37 & 72.28 & 78.65 & 81.7 & 85 & 80 & 80 & 82 & 79.12 & Tuntas \\
\hline 2 & AW & 86.71 & 80.62 & 80.21 & 81.7 & 85 & 81.7 & 80 & 82 & 82.24 & Tuntas \\
\hline 3 & AT & 80.04 & 75.06 & 80.73 & 83.3 & 83.3 & 80 & 80 & 82 & 80.55 & Tuntas \\
\hline 4 & ASN & 73.37 & 72.28 & 80.73 & 83.3 & 86.7 & 86.7 & 85 & 82 & 81.26 & Tuntas \\
\hline 5 & AS & 86.71 & 75.06 & 81.25 & 81.7 & 81.7 & 85 & 85 & 80 & 82.05 & Tuntas \\
\hline 6 & AR & 66.7 & 77.84 & 82.29 & 83.3 & 83.3 & 86.7 & 83.3 & 80 & 80.43 & Tuntas \\
\hline 7 & $\mathrm{D}$ & 73.37 & 83.4 & 79.69 & 83.3 & 81.7 & 81.7 & 83.3 & 80 & 80.81 & Tuntas \\
\hline 8 & DHP & 80.04 & 88.96 & 79.69 & 80 & 81.7 & 81.7 & 85 & 80 & 82.14 & Tuntas \\
\hline 9 & DPP & 73.37 & 91.74 & 79.17 & 83.3 & 86.7 & 83.3 & 86.7 & 82 & 83.28 & Tuntas \\
\hline 10 & DSN & 80.04 & 77.84 & 78.13 & 83.3 & 85 & 81.7 & 80 & 82 & 81 & Tuntas \\
\hline 11 & EY & 86.71 & 80.62 & 79.69 & 81.7 & 85 & 81.7 & 81.7 & 82 & 82.39 & Tuntas \\
\hline 12 & EFS & 93.38 & 75.06 & 79.69 & 80 & 88.3 & 85 & 85 & 82 & 83.55 & Tuntas \\
\hline 13 & FS & 86.71 & 77.84 & 80.73 & 83.3 & 88.3 & 86.7 & 81.7 & 84 & 83.66 & Tuntas \\
\hline 14 & HT & 86.71 & 80.62 & 80.73 & 81.7 & 85 & 85 & 81.7 & 84 & 83.18 & Tuntas \\
\hline 15 & IP & 80.04 & 83.4 & 81.25 & 81.7 & 83.3 & 83.3 & 80 & 84 & 82.12 & Tuntas \\
\hline 16 & M & 80.04 & 75.06 & 79.69 & 81.7 & 85 & 85 & 85 & 84 & 81.94 & Tuntas \\
\hline 17 & OS & 73.37 & 77.84 & 80.21 & 81.7 & 83.3 & 81.7 & 81.7 & 82 & 80.23 & Tuntas \\
\hline 18 & REW & 86.71 & $6: 43$ & 4:00 & 83.3 & 88.3 & 86.7 & 85 & 82 & 82.93 & Tuntas \\
\hline 19 & RDU & 80.04 & 80.62 & 79.17 & 81.7 & 86.7 & 86.7 & 85 & 82 & 82.74 & Tuntas \\
\hline 20 & RH & 73.37 & 80.62 & 79.17 & 83.3 & 86.7 & 86.7 & 83.3 & 82 & 81.89 & Tuntas \\
\hline 21 & SA & 73.37 & 77.84 & 79.69 & 85 & 88.3 & 85 & 83.3 & 82 & 81.81 & Tuntas \\
\hline 22 & SW & 80.04 & 75.06 & 80.21 & 85 & 88.3 & 83.3 & 80 & 82 & 81.74 & Tuntas \\
\hline 23 & $S$ & 80.04 & 83.4 & 80.21 & 81.7 & 90 & 86.7 & 80 & 82 & 83.01 & Tuntas \\
\hline 24 & $S$ & 80.04 & 83.4 & 79.17 & 80 & 88.3 & 90 & 81.7 & 82 & 83.08 & Tuntas \\
\hline 25 & $S$ & 73.37 & 75.06 & 79.17 & 83.3 & 83.3 & 85 & 80 & 80 & 79.9 & Tuntas \\
\hline 26 & SE & 86.71 & 77.84 & 79.17 & 83.3 & 83.3 & 83.3 & 83.3 & 80 & 82.11 & Tuntas \\
\hline 27 & $\mathrm{TS}$ & 80.04 & 77.84 & 80.21 & 83.3 & 83.3 & 86.7 & 81.7 & 80 & 81.64 & Tuntas \\
\hline 28 & $\mathrm{~T}$ & 73.37 & 77.84 & 80.21 & 83.3 & 88.3 & 83.3 & 83.3 & 83 & 81.58 & Tuntas \\
\hline 29 & WW & 80.04 & 80.62 & 79.69 & 81.7 & 86.7 & 81.7 & 81.7 & 83 & 81.89 & Tuntas \\
\hline 30 & YH & 73.37 & 75.06 & 79.69 & 81.7 & 91.7 & 86.7 & 86.7 & 83 & 82.24 & Tuntas \\
\hline
\end{tabular}

\section{KETERANGAN RANAH KOMPETENSI}

1: Unjuk kerja aspek pengetahuan praktik

2: Unjuk kerja aspek pengetahuan kewirausahaan

3: Unjuk kerja aspek sikap kewirausahaan

4: Unjuk kerja aspek keterampilan membuat komponen kolom praktis (individual)

5: Unjuk kerja aspek keterampilan merangkai kolom praktis (kelompok)

6: Unjuk kerja aspek keterampilan merangkai tulangan tutup sumur

7: Unjuk kerja aspek keterampilan membuat begisting dan cor beton

8: Unjuk kerja membuat proposal usaha

9: Mean skor unjuk kerja

Pengukuran ketuntasan kesiapan berwirausaha siswa dilakukan pada dalam pembelajaran di kelas produktif. Tahapan pembelajaran dilakukan sebanyak 4 kali. Untuk merealisasikan implementasi pembelajaran ditetapkan SMKN 2 Pengasih Kulonprogo. Pelaksanaan pembelajaran dilakukan pada semester ganjil. Hal ini dilakukan dengan alasan bahwa siswa kelas XII pada semester genap harus 
dipersiapkan untuk menghadapi kegiatan-kegiatan akademik yang berkaitan dengan ujian nasional.

Berdasarkan skor kompetensi kerja yang didapat siswa, hampir seluruh siswa menyelesaikan pembelajarannya dengan kriteria tuntas. Hal ini ditunjukkan bahwa hampir semua skor keberadaannya diatas nilai KKM > 70. Dengan demikian tingkat kesiapan kewirausahaan siswa SMK yang diajar dengan model pembelajaran kolaborasi dapat dikatakan telah tuntas, artinya siswa diharapkan setelah lulus dari SMK dapat merealisasikan untuk berwirausaha mandiri.

Aktivitas guru dalam pembelajaran kolaborasi diukur berdasarkan indikator-indikator: (1) pendahuluan, (2) kegiatan inti, (3) penutup dan, (4) penggunaan bahasa. Teknis pengukuran aktivitas guru dikenakan pada kelas XII di SMKN 2 Pengasih, Kabupaten Kulonprogo. Aktivitas guru dalam hal ini merupakan aktivitas dalam mengajar dengan mengggunakan model pembelajaran kolaborasi yang mengarah pada kegiatan-kegiatan seperti tersebut pada indikator di atas. Pengamat aktivitas guru adalah empat mahasiswa yang ditugasi oleh peneliti. Mereka mengamati kegiatan guru dalam mengajar, baik guru bidang produktif maupun guru bidang kewirausahaan dengan proporsi dua mahasiswa mengamati aktivitas satu guru bidang produktif dan dua mahasiswa lainnya mengamati aktivitas satu guru bidang kewirausahaan. Pengambilan data melalui instrument penilaian aktivitas guru dilakukan pada pertemuan tatap muka pembelajaran terakhir. Dari hasil analisis data dapat disimpulkan seperti terlihat pada tabel 2.

Tabel 2. Hasil Penilaian Aktivitas Guru pada Pembelajaran

\begin{tabular}{clcc}
\hline \multirow{2}{*}{ No } & \multirow{2}{*}{ Aspek yang dinilai } & \multicolumn{2}{c}{ Hasil Penilaian } \\
\cline { 3 - 4 } & & Mean & Kriteria \\
\hline 1 & Keseluruhan & 88,00 & Aktif \\
2 & Pendahuluan & 17,50 & Aktif \\
3 & Kegiatan inti & 45,50 & Aktif \\
4 & Penutup & 13,80 & Sangat aktif \\
5 & Penggunaan bahasa & 11,30 & Aktif \\
\hline
\end{tabular}

Inti pertanyaan adalah menanyakan bagaimana tentang respon guru terhadap penerapan pembelajaran model ini untuk menumbukan kesiapan berwirausaha siswa SMK. Dalam hasil analisis ini ditenukan bahwa respon guru secara keseluruhan dalam rentang ketegori aktif. 
Aktivitas siswa dalam pembelajaran Model PKT diukur berdasarkan indikator-indikator: (1) konsentrasi siswa saat pembelajaran, (2) mencatat, (3) bertanya pada guru, (4) menjawab pertanyaan guru, (5) mengemukakan pendapat dan (6) penggunaan bahasa. Teknis pengukuran aktivitas siswa dikenakan pada kelas XII di SMKN 2 Pengasih, Kabupaten Kulonprogo. Aktivitas siswa dalam hal ini merupakan aktivitas dalam mengikuti pembelajaran dengan mengggunakan pembelajaran kolaborasi yang mengarah pada kegiatan-kegiatan seperti tersebut pada indikator di atas. Pengamat aktivitas siswa adalah empat mahasiswa yang ditugasi oleh peneliti. Mereka mengamati kegiatan siswa dalam mengikuti pembelajaran. Pengamatan pada prinsipnya ditujukan pada dinamika kelas. Satu mahasiswa pengamat mengamati secara garis besar seperempat dari jumlah siswa yang mengikuti pembelajaran dalam kelas. Dalam hal ini seperempat jumlah siswa dikemas dalam bentuk satu group kerja yang berjumlah antara 4-5 siswa. Pengambilan data melalui instrument penilaian aktivitas siswa dilakukan pada pertemuan tatap muka pembelajaran terakhir. Dari hasil analisis data dapat disimpulkan seperti pada tabel 3.

Tabel 3. Hasil Penilaian Aktivitas Siswa pada Pembelajaran

\begin{tabular}{clcc}
\hline \multirow{2}{*}{ No } & \multicolumn{1}{c}{ Aspek yang dinilai } & \multicolumn{2}{c}{ Hasil Penilaian } \\
\cline { 3 - 4 } & & Mean & Kriteria \\
\hline 1 & Keseluruhan & 60,50 & Aktif \\
2 & Konsentrasi siswa saat pembelajaran & 14,25 & Aktif \\
3 & Mencatat & 12,50 & Aktif \\
4 & Bertanya kepada guru & 12,50 & Aktif \\
5 & Menjawab pertanyaan guru & 7,50 & Aktif \\
6 & Mengemukakan pendapat & 10,00 & Aktif \\
7 & Penggunaan bahasa & 12,50 & Aktif \\
\hline
\end{tabular}

Inti pertanyaan adalah menanyakan bagaimana tentang respon siswa terhadap penerapan pembelajaran kolaborasi untuk menumbukan kesiapan berwirausaha siswa SMK. Dalam hasil analisis ini ditentukan bahwa respon siswa secara keseluruhan dalam rentang ketegori aktif.

\section{KESIMPULAN}

Dari hasil analisis data dan pembahasan dapat disimpulkan sebagai berikut: (1) model pembelajaran kolaborasi ini dapat digeneralisasikan pada mata pelajaran-mata pelajaran lain yang mempunyai karakteriksik sama dengan mata pelajaran pada penelitian ini, (2) melalui pembelajaran ini tercipta pembelajaran yang aktif antara guru dalam mengajar dan siswa dalam belajar, oleh karenanya disarankan pada pihak-pihak terkait seperti guru, kepala sekolah, praktisi wirausaha untuk dapat mendukung implementasi pembelajaran model ini, sebagai alternatif menumbuhkan ketuntasan siswa dalam kesiapan berwirausaha, (3) 
pembelajaran model ini sejalan dengan pembelajaran tematik terpadu yang merupakan suatu pendekatan dalam pembelajaran yang secara sengaja mengaitkan beberapa aspek baik dalam intra mata pelajaran maupun antar mata pelajaran. Oleh karenanya hendaknya dalam pembelajaran ini difokuskan pada: (a) berpusat pada peserta didik, (b) memberi pengalaman langsung pada peserta didik, (c) bersifat luwes, (d) holistik, bahwa pembelajaran tematik terpadu diamati dan dikaji dari beberapa mata pelajaran sekaligus, (e) otentik, artinya informasi dan pengetahuan yang diperoleh sifatnya menjadi nyata, (f) aktif, artinya peserta didik perlu terlibat langsung dalam proses pembelajaran mulai dari perencanaan, pelaksanaan hingga proses penilaian.

\section{DAFTAR PUSTAKA}

Anderson, L.W. \& Block, J.H. (1987). Mastery learning models. In Michael J. Dunkin (Ed). The International Encyclopedia of Teaching and Teacher Education. Oxford: Pergamon Press.

Borg, W.R, and Gall. M.D. (1989). Educational Research An Introduction. New York: Pitman Publishing Inc.

Chaplin, J.P. (2006). Kamus lengkap psikologi. (Terjemahan Kartini-Kartono). Jakarta: PT Raja Grafindo Persada.

Dali Gulo. (1984). Kamus psychology. Bandung: Tonis.

Edward. (1982). Cara mengklasifikasikan kemampuan, Padang: FKT-IKIP Padang.

Kemendiknas. (2010). Pengembangan pendidikan kewirausahaan. Jakarta: Badan Penelitian dan pengembangan Pusat Kurikulum.

Matthoriq, Ria Triwastuti, \& Nurul Hidayah. (2009). Konsep kaize sebagai basis pendidikan kewirausahaan di AMK dalam upaya mengurangi pengangguran Di Jawa Timur. Jurnal, Research Study Club (RSC) FIA UB 55 Edisi ke 2.

National Content Standards for Entrepreneurship Education. (2013). Diambil dari http.//www.entre-ed.org/standards toolkit/helpful download.htm. pada tanggal 12 Januari 2013.

Slameto. (2003). Belajar dan faktor-faktor yang mempengaruhi. Jakarta: Rineka Cipta.

Suryana. (2006). Kewirausahaan pedoman praktis: kiat dan proses menuju sukses. Edisi 3. Jakarta: Salemba Empat. 